\title{
Green apple baked snacks functionalized with edible coatings of methylcellulose containing Lactobacillus plantarum
}

\author{
María José Tavera-Quiroz ${ }^{a}$, Nelson Romano ${ }^{b}$, Pablo Mobili ${ }^{b, c}$, \\ Adriana Pinotti ${ }^{a, d}$, Andrea Gómez-Zavaglia ${ }^{b}$, Nora Bertola ${ }^{a, c, *}$ \\ ${ }^{a}$ Laboratory of Biodegradable Films, Center for Research and Development in Food Cryotechnology (CIDCA, \\ CCT-CONICET La Plata), Argentina \\ ${ }^{\mathrm{b}}$ Laboratory of Microbiology, Center for Research and Development in Food Cryotechnology (CIDCA, CCT- \\ CONICET La Plata), Argentina \\ c Faculty of Exact Sciences, UNLP, La Plata, Argentina \\ d Faculty of Engineering, UNLP, La Plata, Argentina
}

\section{A R T I C L E I N F O}

\section{Article history:}

Received 14 November 2014

Received in revised form 13 April

2015

Accepted 14 April 2015

Available online

Keywords:

Lactobacillus plantarum

Probiotics

Apple snacks

Methylcellulose

Isomalt

Fructooligosaccharides

\begin{abstract}
A B S T R A C T
The aim of the present work was to develop a healthy snack as a vehicle of probiotic bacteria. Apple snacks were coated with methylcellulose films containing fructooligosaccharides and Lactobacillus plantarum CIDCA 83114. Dehydration of the snacks at $60^{\circ} \mathrm{C}$ for 50 min allowed obtaining a product with water content, crispness and visual aspect similar to those before applying the film-forming solution, without major detrimental effects for microorganisms. Sensory attributes of coated snacks were evaluated by an experienced sensory panel, receiving good scores in taste $(6.5 \pm 0.6)$, color $(7.7 \pm 0.4)$, texture $(7.2 \pm 0.4)$ and overall acceptability $(7.2 \pm 0.3)$. Storage of the snacks at $20^{\circ} \mathrm{C}$ and $60 \% \mathrm{RH}$ caused only a mild decrease in the bacterial cultivability after 90 days ( $1.4 \log \mathrm{CFU} / \mathrm{g})$, and a significant number of bacteria were still alive after the simulated gastric $\left(5.5 \times 10^{6} \pm 0.7 \times 10^{6} \mathrm{CFU} / \mathrm{g}\right)$ and intestinal $\left(1.0 \times 10^{6} \pm 0.4 \times 10^{6} \mathrm{CFU} / \mathrm{g}\right)$ digestions of the stored samples. The force-deformation curves showed a typical pattern of brittle materials up to 90 days of storage. The $\mathrm{T}_{\mathrm{g}}$ followed a similar trend, in accordance with the constant moisture content. An organoleptically attractive food product was obtained which after 90 days of storage presented a high load of cultivable lactobacilli $\left(2.0 \times 10^{8} \pm 0.7 \times 10^{8} \mathrm{CFU} / \mathrm{g}\right)$. This concentration is well above the minimum considered necessary $\left(10^{6}-10^{7} \mathrm{CFU} / \mathrm{g}\right)$ to obtain the benefits of probiotic consumption.
\end{abstract}

(c) 2015 Elsevier Ltd. All rights reserved.

\section{Introduction}

According to the FAO/WHO (2002) definition, probiotics are live organisms that when administered in adequate amounts $\left(10^{6}-10^{7} \mathrm{CFU} / \mathrm{g}\right)$ confer health benefits to the host. The regula- tion of the gastrointestinal tract, stimulation of the immune system, reduction of serum cholesterol levels, relief of lactose intolerance and irritable bowel syndrome symptomatology, prevention of cardiovascular disease and different forms of cancer are among the health benefits ascribed to probiotics (Chong, 2014; Kumar et al., 2010; Saad, Delattre, Urdaci, Schmitter, \&

\footnotetext{
* Corresponding author. Calle 47 y 116 La Plata (1900), Buenos Aires, Argentina. Tel.: +54 221 4890741; fax: +54 2214254853.

E-mail address: bertolanora@gmail.com (N. Bertola).
}

http://dx.doi.org/10.1016/j.jff.2015.04.024

1756-4646/@ 2015 Elsevier Ltd. All rights reserved. 
Bressollier, 2013). In general, probiotics are consumed through food products and represent a significant part of the functional foods market (Tripathi \& Giri, 2014). The most extended matrices for the incorporation of probiotics are dairy products, including yoghurts, fermented milks and milk-based desserts, powdered milk for newborn infants, ice-creams, butter and different types of cheese (Champagne, Gardner, \& Roy, 2005). Other non-dairy products, like mayonnaise, encapsulated products, and fermented foods of vegetable origin, have also been used as probiotic vehicles (Champagne et al., 2005; Komatsu, Buriti, \& Saad, 2008; Saad, 2006).

The awareness of consumers about the impact of food on health has strongly contributed to increase the demand of functional foods (Tripathi \& Giri, 2014). As the consumption of snacks is a well-established habit all around the world, these products may represent an appropriate matrix to deliver probiotic bacteria (Noorbakhsh, Yaghmaee, \& Durance, 2013). For the development of baked snacks containing probiotics, different challenges shall be overcome. Among them, bacterial injuries and loss of viability derived from the processing conditions (i.e., heat treatments, mechanical and osmotic stress, etc.) are the most critical (Bustos \& Bórquez, 2013; Lapsiri, Bhandari, \& Wanchaitanawong, 2012). In addition, the properties of the snack (crispness, texture, color, etc.) cannot be disregarded because the loss of these properties may lead to a non-acceptance of the product, even when probiotics are viable. Therefore, the development of snacks bearing probiotics requires a strict control of all these aspects. Immobilization of probiotics in edible films (single or composite biopolymer substrates) appears as a promising route to protect them and to coat food systems where probiotics cannot be incorporated by direct inoculation. Moreover, the film matrices usually protect microorganisms against both food processing and gastrointestinal conditions (Soukoulis, Behboudi-Jobbehdar, Yonekura, Parmenter, \& Fisk, 2014; Soukoulis, Yonekura, et al., 2014). Different matrices have been used to form the films, including proteins, polysaccharides and prebiotics (Kanmani \& Lim, 2013; Rößle, Brunton, Gormley, Ross, \& Butler, 2010; Tapia et al., 2007). Soukoulis, Behboudi-Jobbehdar, et al. (2014) observed that the supplementation of edible gelatin-based films with prebiotics ameliorate the storage stability of immobilized Lactobacillus rhamnosus GG. In the same way, López de Lacey, López-Caballero, Gómez-Estaca, Gómez-Guillén, and Montero (2012) and López de Lacey, López-Caballero, and Montero (2014) incorporated probiotic strains into bioactive films contributing to an adequate conservation of fish.

In a recent article, we demonstrated that methylcellullose (MC) films are adequate matrices to immobilize lactobacilli (Romano et al., 2014). Furthermore, the incorporation of fructooligosaccharides (FOS) into the film matrix contributes to protect microorganisms during dehydration and storage, also providing prebiotic properties to the obtained films (Romano et al., 2014).

Altamirano-Fortoul, Moreno-Terrazas, Quezada-Gallo, and Rosell (2012) obtained functional bread combining the microencapsulation of Lactobacillus acidophilus and starch based coatings, with an adequate bacterial survival after baking and storage. According to Soukoulis, Yonekura, et al. (2014) the application of two different edible films (gelatin and alginate) containing Lactobacillus rhamnosus GG on the crust of prebaked bread turned out to be an appropriate system for the delivery of probiotics.

Isomalt is an equimolar mixture of O-D-glucopyranosyl1,6-D-sorbitol and O-D-glucopyranosyl-1,6-D-manitol. It is known as a low-glycemic and low-energy sweetener, with reported prebiotic properties (Gostner et al., 2006). The sweetening power of isomalt lies between 0.45 and 0.6 compared with that of sucrose $(=1.0)$. It has a pure sweet taste similar to sucrose without any aftertaste, and reinforces flavor transfer in foods (O'Brien-Nabors, 2001). From a technological point of view, isomalt is a non-hygroscopic compound that can be used in replacement of other sugars and extend the shelf life of food products (Cammenga \& Zielasko, 1996; Raudonus, Bernard, Janßen, Kowalczyk, \& Carle, 2000).

Radowski (2006) and Martínez-Cervera, Salvador, and Sanz (2014) used isomalt in the formulation of food products submitted to heat treatments, like muffins and breakfast cereals, whereas Lapsiri et al. (2012) also informed about the protection of Lactobacillus plantarum during spray-drying. Considering this background, we have recently developed a snack based on green apples with the addition of isomalt (Tavera-Quiroz, Urriza, Pinotti, \& Bertola, 2015). In the present work, we aim to coat apple snacks with edible MC films functionalized with L. plantarum CIDCA 83114. L. plantarum CIDCA 83114 is an especially interesting strain because of both its technological (Golowczyc, Gerez, et al., 2011; Golowczyc, Silva, Teixeira, De Antoni, \& Abraham, 2011) and inhibitory properties against Escherichia coli O157:H7, Shigella and Salmonella (Hugo, Kakisu, De Antoni, \& Pérez, 2008; Kakisu, Abraham, Tironi Farinati, Ibarra, \& De Antoni, 2013a; Kakisu, Bolla, Abraham, de Urraza, \& De Antoni, 2013b). The quality of the novel system was studied focusing on its microbiological, physicochemical and sensory properties. Cultivability of microorganisms and bacterial resistance to simulated gastrointestinal conditions were assessed immediately after obtaining the snacks and during storage at $20^{\circ} \mathrm{C}$, up to 90 days. In addition, moisture, texture and color were also determined before and after storage. The sensory properties were assessed on a panel with experience in sensory evaluation.

\section{Materials and methods}

\subsection{Stock culture preparation and growth conditions}

L. plantarum CIDCA 83114 was isolated from kefir grains (Garrote, Abraham, \& De Antoni, 2001) and maintained frozen at $-80^{\circ} \mathrm{C}$ in $120 \mathrm{~g} / 1$ skim milk (Difco, Detroit, MI, USA). The microorganisms were reactivated in MRS broth (de Man, Rogosa, \& Sharpe, 1960) incubated at $30^{\circ} \mathrm{C}$ in aerobic conditions without agitation. The resulting culture was inoculated (1\%,v/v) in $100 \mathrm{ml}$ of fresh MRS broth and incubated in the same conditions. Cultures in early stationary phase (grown overnight to attain approximately $2.0 \times 10^{10} \mathrm{CFU} / \mathrm{ml}$ ) were harvested by centrifugation at $7000 \mathrm{~g}$ for $10 \mathrm{~min}$ and washed twice with $8.5 \mathrm{~g} / 1 \mathrm{NaCl}$. Bacterial pellets were kept to be incorporated into the film forming solution (see section 2.2 "Preparation of the film forming solution"). 


\subsection{Preparation of the film forming solution}

1.5 g MC (A4M, Methocel, Dow, Midland, MI, USA) were slowly dispersed in $50 \mathrm{ml}$ of distilled water at $80^{\circ} \mathrm{C}$ under constant stirring for $1 \mathrm{~h}$. Once a homogeneous system was obtained, a total volume of $80 \mathrm{ml}$ was made up with cold distilled water. Afterward, citric acid (Biopac, Aero Camino Goleta, CA, USA) (50 g/l in MC) and sorbitol (Merck, Darmstadt, Germany) (2.5 g/ l) were added as cross-linking and plasticizing agents, respectively. FOS (Orafti Beneo p95, Mannheim, Germany) were also added to the hydrocolloid solution, to a final concentration of $30 \mathrm{~g} / \mathrm{l}$. The resulting solution was sterilized using $0.22 \mu \mathrm{m}$ sterile nylon syringe filters (Millipore, Bedford, MA, USA). Bacterial pellets obtained in the previous step (section 2.1. "Stock culture preparation and growth conditions") were suspended in $4 \mathrm{ml}$ of the film forming solution, yielding a concentration of $3.1 \times 10^{11} \pm 0.3 \times 10^{11} \mathrm{CFU} / \mathrm{ml}$ of L. plantarum in the solution.

\subsection{Apple snack preparation}

For the development of the snacks, Granny Smith (Malus domestica) apples, selected by size and appearance, were purchased from the local market. The snacks were prepared following the procedure described by Tavera-Quiroz, Urriza, Pinotti, and Bertola (2014) and Tavera-Quiroz et al. (2015). In brief, apple ring slices of $2.0 \pm 0.2 \mathrm{~mm}$ thickness were impregnated in calcium lactate gluconate (Food and pharma grade, Jungbunzlauer, Germany) for 2 min and then osmotically dehydrated by immersion in a $300 \mathrm{~g} / \mathrm{l}$ solution containing isomalt (Beneo-Palatinit, Germany) and maltodextrin (Food grade, Parafarm, Buenos Aires, Argentina) in a 2:1 ratio. Prior to the immersion of the samples, $20 \mathrm{~g} / \mathrm{l}$ of ascorbic acid (AA) was added to the solutions. Afterward, the apple rings were baked for $30 \mathrm{~min}$ at $140{ }^{\circ} \mathrm{C}$ in a forced convection oven to obtain the snacks.

In a next step, $100 \mu \mathrm{l}$ of the solution containing bacteria (section 2.2 "Preparation of the film forming solution") were brushed to uniformly coat the upper surface of the baked snacks and dried again in a forced convection oven. Five different temperature/time combinations were evaluated: $140{ }^{\circ} \mathrm{C} /$ $3 \mathrm{~min} ; 100{ }^{\circ} \mathrm{C} / 5 \mathrm{~min} ; 80^{\circ} \mathrm{C} / 20 \mathrm{~min}, 60^{\circ} \mathrm{C} / 50 \mathrm{~min}$ and $50^{\circ} \mathrm{C} /$ $90 \mathrm{~min}$. For each temperature, the drying time was optimized so that the samples recovered similar sensory and physical properties than the non-coated snacks, without harmful effects for lactobacilli.

After the drying steps, the snacks were packaged in thermosealed biaxially oriented polypropylene bags (Vitopel S.A., Villa del Totoral, Córdoba, Argentina). Samples were stored in a temperature controlled chamber at $20{ }^{\circ} \mathrm{C}$ and $60 \%$ relative humidity $(\mathrm{RH})$. Non-coated samples were used as controls.

\subsection{Physicochemical properties of the snacks}

Moisture, texture and color were determined after drying the samples in the optimal conditions and after 15, 30, 45, 60 and 90 days of storage (section 2.3 "Apple snack preparation"). Uncoated snacks were used as controls.

\subsubsection{Determination of moisture content}

The moisture contents of the snacks were determined by measuring their weight loss upon drying in a vacuum oven at $70^{\circ} \mathrm{C}$ until constant weight (Association of Official Analytical Chemists, 1980). Moisture results were expressed as grams of water per $100 \mathrm{~g}$ of dried sample (ds).

\subsubsection{Texture analysis}

Snack texture was evaluated at room temperature in a TA.XT2i texturometer (Stable Micro Systems, Surrey, UK) by using a spherical probe of $5 \mathrm{~mm}$ diameter $\mathrm{P} / 5 \mathrm{~S}$, at a constant rate of $1 \mathrm{~mm} / \mathrm{s}$. The probe moved down onto the sample which was centrally located over the circular support rig HDP/CFS, up to the point of fracture. Curves of force as a function of deformation were automatically recorded by the Texture Expert Exceed software (Stable Microsystems). Deformation at break/ fracture value (extension at the moment of rupture, $\mathrm{mm}$ ), maximum breaking force $(\mathrm{N})$, taken as the penetration resistance of the sample, and elastic modulus $(\mathrm{N} / \mathrm{mm})$, calculated as the slope of force-deformation curve, were determined. Groups of 10 snacks were individually tested and the average of the determinations was determined.

\subsubsection{Color measurements}

Snack color was determined by means of a Minolta colorimeter CR 400 Series (Osaka, Japan). The CIELab scale was used, and lightness (L) and chromaticity parameters $\mathrm{a}^{*}$ (red-green) and b* (yellow-blue) were measured. Browning index (BI) has been reported as an important parameter in processes where enzymatic or nonenzymatic browning takes place (Tavera-Quiroz et al. (2014). It was calculated as follows:

$\mathrm{BI}=\frac{100}{0.172}\left(\frac{\mathrm{a}^{*}+1.75 \mathrm{~L}}{5.645 \mathrm{~L}+\mathrm{a}^{*}-3.012 \mathrm{~b}^{*}}-0.31\right)$

Each slice of apple snack (0.500 g) was gently triturated by using a sterilized manual mortar and then re-hydrated with $5 \mathrm{ml}$ of $8.5 \mathrm{~g} / 1 \mathrm{NaCl}$. After complete rehydration of the triturated snacks, the suspensions were serially diluted in $8.5 \mathrm{~g} / \mathrm{l}$ $\mathrm{NaCl}$, plated on MRS agar and incubated at $30^{\circ} \mathrm{C}$ for $24 \mathrm{~h}$. This process was carried out immediately after drying in the optimal conditions and during storage (times equal to 15, 30, 45, 60 and 90 days) (section 2.3 "Apple snack preparation").

\subsection{Microstructure analysis}

Samples were carefully deposited onto carbon tabs (Agar Scientific, Stansted, UK), coated with carbon (Agar turbo carbon coater) and placed on the stage of a FEI Quanta 3D 200 dual beam Focused Ion Beam Scanning Electron Microscope (FIMSEM, FEI, Hillsboro, OR, USA). Images were acquired by using secondary electron imaging at an accelerating voltage of $5 \mathrm{kV}$. The observations were carried out on samples after obtaining the apple snacks (section 2.3 "Apple snack preparation").

\subsection{Thermal properties}

Thermal properties of apple snacks obtained in section 2.3 "Apple snack preparation" were determined by using a differential scanning calorimeter DSC-Q100 controlled by a TA 5000 module (TA Instruments, New Castle, DE, USA). The first scan was performed in the $-70{ }^{\circ} \mathrm{C}$ to $200^{\circ} \mathrm{C}$ range at $10^{\circ} \mathrm{C} / \mathrm{min}$. After 
the first scan was completed, the samples were cooled until $-70^{\circ} \mathrm{C}$ and then, a second scan was recorded between -70 and $250^{\circ} \mathrm{C}$ at $10^{\circ} \mathrm{C} / \mathrm{min}$. The glass transition temperatures $\left(\mathrm{T}_{\mathrm{g}}\right)$ were obtained from thermograms by using the Universal Analysis V1.7F software (TA Instruments). Uncoated samples were used as controls.

\subsection{Determination of ascorbic acid (AA)}

The content of AA was determined $24 \mathrm{~h}$ after the drying process on $1 \mathrm{~g}$ of frozen snacks (obtained in section 2.3 "Apple snack preparation") by high performance liquid chromatography (Waters, model R-414, Milford, MA, USA). The method consisted of an isocratic elution procedure with UV-Visible detection at $245 \mathrm{~nm}$. AA (Food grade, Parafarm) was used as standard.

The frozen snacks were mixed with $5 \mathrm{ml}$ of an aqueous solution $50 \mathrm{~g} / \mathrm{l}$ of metaphosporic acid (Sigma Aldrich, St. Louis, MO, USA) for $15 \mathrm{~min}$ and centrifuged at $2000 \mathrm{rpm}$ for $10 \mathrm{~min}$ (Rolco CM 2036, Buenos Aires, Argentina). Separations were carried out on a $5 \mathrm{~mm}$ RP C18 column of $150 \mathrm{~mm}-4.6 \mathrm{~mm}$ (WAT 045905, Waters, Dublin, Ireland). A mixture of $5 \mathrm{~g} / \mathrm{l}$ metaphosporic acid-acetonitrile (93:7) was employed as mobile phase (Nojavan et al., 2008).

\subsection{In vitro digestion}

The effect of simulated gastrointestinal conditions was evaluated immediately after obtaining the apple snacks (time equal to 0) and also during storage at days 30,60 and 90 .

The test was divided into two stages, gastric digestion (pepsin, pH 2.5) (Sigma Aldrich) and intestinal digestion (pancreatin, bile salts, pH 7.5) (Sigma Aldrich) (adapted from Soukoulis, Yonekura, et al., 2014). In brief, $0.500 \mathrm{~g}$ of snack (1 slice) were triturated and suspended in $2.5 \mathrm{ml}$ of $8.5 \mathrm{~g} / \mathrm{l} \mathrm{NaCl}$. Then, $2.5 \mathrm{ml}$ of 2-fold concentrated simulated gastric juice (porcine pepsin 3200 units/ml, $7.2 \mathrm{mM} \mathrm{CaCl}_{2}, 3 \mathrm{mM} \mathrm{MgCl}_{2}, 98 \mathrm{mM}$ $\mathrm{NaCl}, 24 \mathrm{mM} \mathrm{KCl}, 12.8 \mathrm{mM} \mathrm{KH}_{2} \mathrm{PO}_{4}, \mathrm{pH}$ 2.5) were added and the $\mathrm{pH}$ was adjusted to 2.5. The samples were incubated for $1 \mathrm{~h}$ at $37^{\circ} \mathrm{C}$ under continuous shaking (130 rpm, MaxQ 4000, Thermo Scientific, USA). The gastric stage digestion was stopped by raising the $\mathrm{pH}$ to 6.5. Afterward, simulated intestinal juice (10 mg/ml pancreatin, $20 \mathrm{mg} / \mathrm{ml}$ bile salts, $100 \mathrm{mM} \mathrm{NaHCO}_{3}$ ) was added and the $\mathrm{pH}$ was adjusted to 7.5. The resulting solution was incubated for $2 \mathrm{~h}$ at $37^{\circ} \mathrm{C}$, under continuous shaking (130 rpm, MaxQ 4000, Thermo Scientific, Waltham, MA, USA).

After each stage, aliquots of $1 \mathrm{ml}$ digesta were diluted in $8.5 \mathrm{~g} / \mathrm{l} \mathrm{NaCl}$ and plated on MRS agar for bacterial enumeration, as described in section 2.5 "Bacterial cultivability".

\subsection{Sensory analysis}

A sensory panel was performed to evaluate the acceptance of the snacks coated with MC films containing bacteria $24 \mathrm{~h}$ after the drying process in the optimal conditions (section 2.3 "Apple snack preparation"). Uncoated samples were used as controls.

A panel composed of 50 members with experience in sensory evaluation was selected among the personnel of CIDCA (La Plata, Buenos Aires, Argentina) who like snacks or are regular consumers of snacks. They were between 25 and 55 years old. Samples were randomly coded and presented to the panel member in trays with instructions for the evaluation. The analyzed attributes were appearance, color, texture, taste and overall acceptability, using a nine point hedonic scale for each. The panelists were asked to indicate the score of each sensory descriptor and a score for overall acceptability, on a scale ranging from 1 (dislike extremely) to 9 (like extremely). A score equal to five was used as a minimum threshold for acceptability. For each one of these attributes, the relative frequency of the panelist responses was reported.

\subsection{Statistical analysis}

All experiments were performed on triplicate samples. The relative differences were reproducible irrespective of the cultures used. Analysis of variance (ANOVA) was used to analyze the results obtained using the statistical program Infostat v2009 software (Córdoba, Argentina). Comparison of means by Fisher LSD mean were tested, and if $\mathrm{P}<0.05$ the difference was considered statistically significant.

\section{Results and discussion}

\subsection{Drying process}

The delivery of probiotics through ingestion of functional foods represents a challenge because of both technological and gastrointestinal conditions. In fact, not all strains are able to survive the food processing and storage. Furthermore, the gastrointestinal tract is detrimental to several strains (Rajam, Karthik, Parthasarathi, Joseph, \& Anandharamakrishnan, 2012; Senaka Ranadheera, Evans, Adams, \& Baines, 2014; Tripathi \& Giri, 2014). Thermal treatments are a critical issue because obtaining crispy and crunchy snacks requires the use of high temperatures that are deleterious for the bacteria.

Coating is a challenging step because of two main reasons. From one side, brushing dried and crispy bare snacks with a film forming solution (liquid) may soften them and deteriorate their sensory properties. To avoid this, the apple snacks were coated on their upper surface with a uniformly spread thin layer of film forming solution $(100 \mu \mathrm{l})$ containing L. plantarum CIDCA 83114. The number of microorganisms contained in these $100 \mu \mathrm{l}$ was referred to the weight of apple snacks and considered as $\mathrm{N}_{\mathrm{i}}\left(\mathrm{N}_{\mathrm{i}}: 6.2 \times 10^{10} \pm 0.6 \times 10^{10} \mathrm{CFU} / \mathrm{g}\right.$ snack).

The time/temperature of this thermal treatment required for MC to form the film must be reduced as much as possible to avoid deleterious effect of heat on microorganisms. The European Food Safety Agency (EFSA) and the Food and Drug Administration (FDA) require at least $10^{6}-10^{7} \mathrm{CFU} / \mathrm{g}$ of probiotic product at the moment of being ingested (Hill et al., 2014; Tripathi \& Giri, 2014). In our previous work, we defined a combination of $2.5 \mathrm{~h}$ at $40{ }^{\circ} \mathrm{C}$ to obtain MC films containing L. plantarum CIDCA 83114 (Romano et al., 2014). However, in the case of snacks, shorter times are needed because the volume of MC films spread on the apple snacks is much lower (100 $\mu \mathrm{l}$ vs $1.5 \mathrm{ml}$ in the previous work) (Romano et al., 2014). Therefore, different temperature/time combinations were analyzed to determine a condition that allows a complete drying of the coating without bacterial detrimental effects (Fig. 1). Drying at 


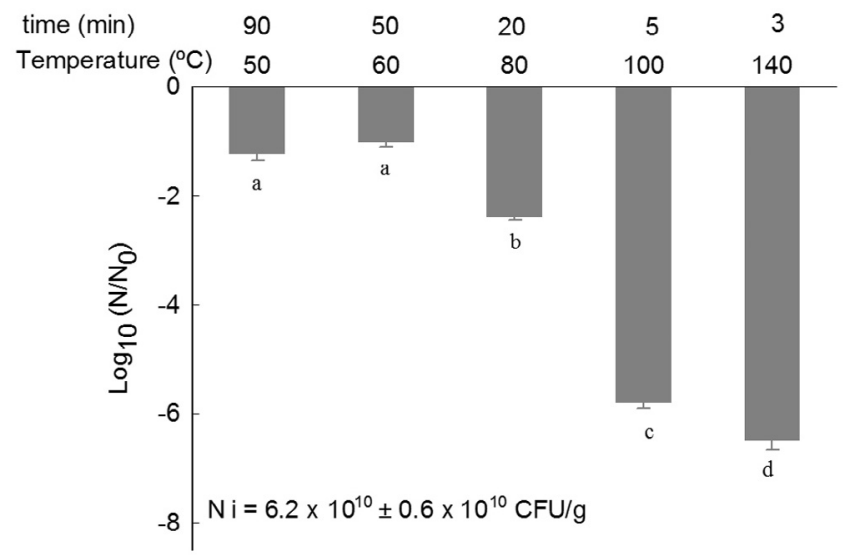

Fig. 1 - Viability of L. plantarum CIDCA 83114 immobilized in methylcellullose (MC) films after different temperature/ time treatments of the apple snacks. Different letters indicate significant differences $(P<0.05)$.

temperatures above $80^{\circ} \mathrm{C}$ for short periods yielded a product of good quality in terms of visual aspect and crispness. In spite of the short times of heating, these treatments caused undesirable death of microorganisms (3 log CFU/g or more). Lower drying temperatures caused less mortality but required longer treatments. Taking this into account, heating at $60^{\circ} \mathrm{C}$ for $50 \mathrm{~min}$ was selected as the drying condition for further experiments. This condition allowed obtaining a product with a constant water content, crispness and visual aspect similar to those before applying the film-forming solution, without major detrimental effects for microorganisms (Fig. 1).

\subsection{Microbiological properties}

Considering that storage conditions may lead to sub-lethal damage, and damaged microorganisms may be more prone to harmful conditions (Tymczyszyn, Díaz, Gómez-Zavaglia, \& Disalvo, 2007a; Tymczyszyn, Gómez-Zavaglia, \& Disalvo, 2007b), we decided to evaluate the effect of simulated gastrointestinal conditions not only after preparing the snacks (time equal to zero) but also during storage up to 90 days. Results for cultivability during storage are presented in Fig. $2 \mathrm{a}$, and results for cultivability during storage followed by exposure to simulated gastrointestinal conditions, in Fig. $2 \mathrm{~b}$.

Before storage, samples showed an initial load $\left(\mathrm{N}_{0}\right)$ of $7.0 \times 10^{9} \pm 0.9 \times 10^{9} \mathrm{CFU} / \mathrm{g}$. Storage at $20{ }^{\circ} \mathrm{C}$ and $60 \% \mathrm{RH}$ caused a steady decrease in the bacterial cultivability, yielding a cumulative viability loss of $1.4 \log$ CFU/g after 90 days (Fig. 2a). Nevertheless, the bacterial load $\left(2.0 \times 10^{8} \pm 0.7 \times 10^{8} \mathrm{CFU} / \mathrm{g}\right)$ at this point was still above the minimum necessary $\left(10^{6}-10^{7} \mathrm{CFU} /\right.$ g) to obtain the benefits of probiotic consumption (Hill et al., 2014; Tripathi \& Giri, 2014).

To exert any noticeable probiotic effect, bacteria must reach the gut alive in sufficient quantities. To achieve this goal they must overcome the harsh gastric (very low $\mathrm{pH}$, proteases) and intestinal (bile salts, proteases, lipases, nucleases) conditions. The ability to surpass such physiological barriers is not necessarily related to the ability of surviving the storage conditions. Therefore, it should be assessed earlier whether a
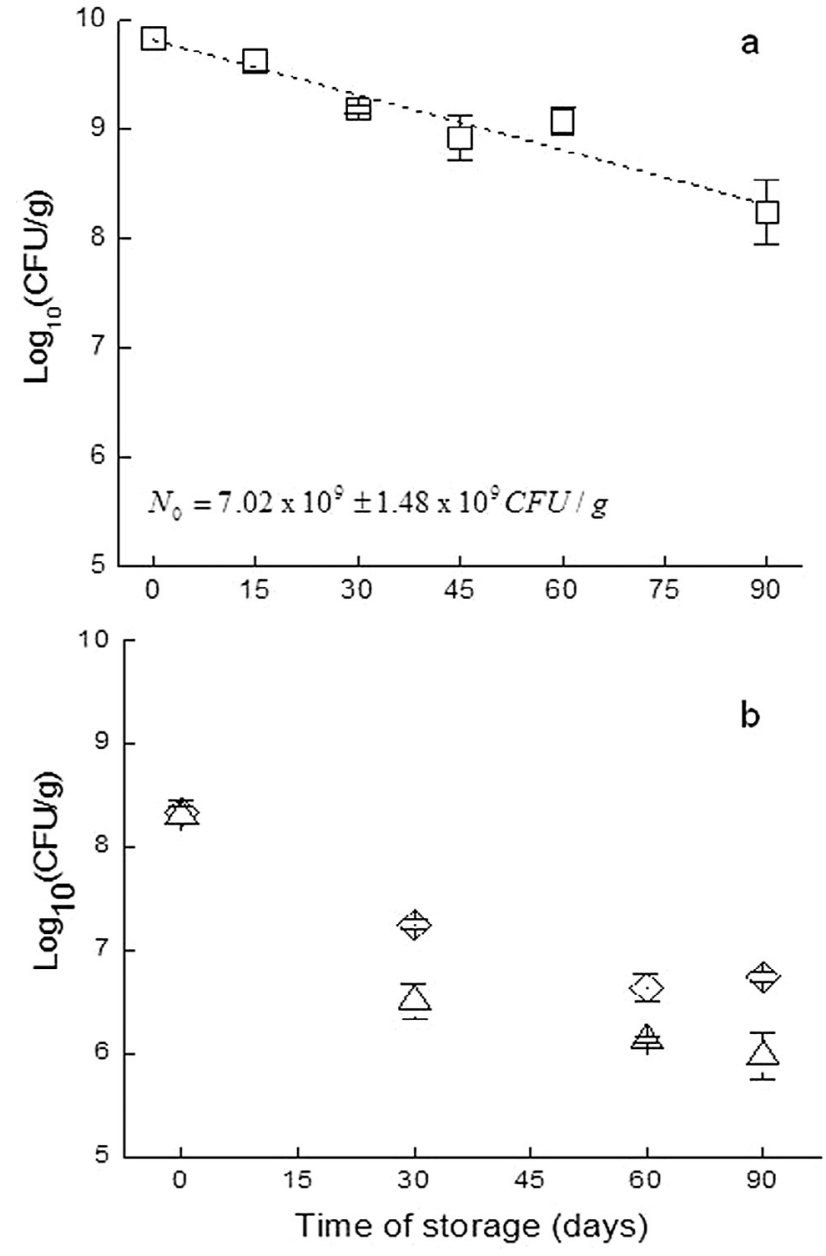

Fig. 2 - Viability of L. plantarum CIDCA 83114 immobilized in methylcellullose films coating apple snacks at different storage times $(a, \square)$, and in the stored snacks exposed to in vitro simulated gastric conditions $(b, \diamond)$ and then exposed to simulated intestinal conditions $(b, \Delta)$. Values represent the average of three independent samples $\pm S D$.

functional food possesses any probiotic potential. In spite of that, only few authors have evaluated the detrimental effect of gastrointestinal conditions on the bacterial cultivability of stored food products bearing probiotics (Bedani, Vieira, Rossi, \& Saad, 2014; Buriti, Castro, \& Saad, 2010). In the present work, the exposure of the coated snacks to simulated gastric conditions immediately after obtaining the snack (time equal to zero) led to a decrease of $1.5 \mathrm{log} \mathrm{CFU} / \mathrm{g}$ in the cultivability of bacterial cells $\left(2.4 \times 10^{8} \pm 0.6 \times 10^{8} \mathrm{CFU} / g\right)$ (Fig. 2b). No further significant decrease of cultivability was observed upon exposure to simulated intestinal digestion $\left(2.0 \times 10^{8} \pm 0.4 \times 10^{8} \mathrm{CFU} /\right.$ g) $(\mathrm{P}>0.05)$.

When snacks were stored for 30 days or more, and then submitted to simulated gastrointestinal conditions, a more marked decrease in cultivability was observed after the gastric and intestinal digestions (Fig. $2 b$ ). This suggests that the damage suffered by microorganisms during drying and further storage significantly diminished bacteria stability under gastrointestinal conditions. The results depicted in Fig. $2 \mathrm{~b}$ confirm that determining the effects of simulated gastrointestinal 
Table 1 - Moisture content, color and mechanical parameters of the control and apple snacks coated with

methylcellulose film loaded with L. plantarum CIDCA 83114 stored at $20^{\circ} \mathrm{C}$ and $60 \% \mathrm{RH}$. Control: non-stored uncoated snacks.

\begin{tabular}{|c|c|c|c|c|c|c|}
\hline Product & $\begin{array}{l}\text { Time } \\
\text { (days) }\end{array}$ & $\begin{array}{l}\text { Moisture } \\
\left(g_{\text {water }} / 100 g_{d s}\right)\end{array}$ & $\begin{array}{l}\text { Lightness } \\
\text { (L) }\end{array}$ & $\begin{array}{l}\text { Browning } \\
\text { index (BI) }\end{array}$ & $\begin{array}{l}\text { Deformation } \\
(\mathrm{mm})\end{array}$ & $\begin{array}{l}\text { Elastic modulus } \\
(\mathrm{N} / \mathrm{mm})\end{array}$ \\
\hline \multirow[t]{5}{*}{ Control } & 0 & $1.8 \mathrm{a}, \mathrm{b}^{*}(0.4)^{* *}$ & 64.0a,b (1.2) & 44.0a (2.2) & $1.2 \mathrm{a}, \mathrm{b}(0.1)$ & $1.1 \mathrm{a}, \mathrm{b}(0.1)$ \\
\hline & 30 & $1.4 \mathrm{a}(0.1)$ & 63.0a (1.7) & 44.0a (2.2) & $1.2 \mathrm{a}, \mathrm{b}(0.2)$ & $1.3 b(0.2)$ \\
\hline & 45 & $2.7 b, c, d(0.2)$ & $63.2 \mathrm{a}, \mathrm{b}(0.8)$ & $45.0 \mathrm{a}, \mathrm{b}(1.4)$ & $1.3 a, b(0.3)$ & $0.9 \mathrm{a}, \mathrm{b}(0.2)$ \\
\hline & 60 & $3.2 \mathrm{~d}$,e $(0.6)$ & 63.0a,b (1.1) & 46.0a,b (1.1) & $1.3 a, b(0.1)$ & $0.82 a, b(0.03)$ \\
\hline & 90 & $3.8 \mathrm{e}(0.6)$ & 67.0a,b (1.4) & $45.0 \mathrm{a}, \mathrm{b}(1.3)$ & $1.6 \mathrm{~b}(0.2)$ & $0.61 \mathrm{a}(0.01)$ \\
\hline \multirow[t]{6}{*}{ Coated snack } & 0 & $3.0 b^{*}(0.3)^{* *}$ & 69.0b (1.5) & $57.0 \mathrm{c}(2.9)$ & $0.82 \mathrm{a}(0.07)$ & $1.1 \mathrm{a}, \mathrm{b}(0.2)$ \\
\hline & 15 & $2.5 b, c, d(0.9)$ & $70.0 \mathrm{~b}(1.6)$ & $51.0 b, c(1.5)$ & $1.2 \mathrm{a}, \mathrm{b}(0.2)$ & $1.2 \mathrm{a}, \mathrm{b}(0.2)$ \\
\hline & 30 & $2.6 \mathrm{~b}, \mathrm{c}, \mathrm{d}(0.4)$ & 65.0a,b (1.1) & $55.0 \mathrm{c}(2.1)$ & $1.1 \mathrm{a}, \mathrm{b}(0.1)$ & $0.99 a, b(0.03)$ \\
\hline & 45 & $2.4 \mathrm{~b}, \mathrm{c}(0.9)$ & $66.3 a, b(0.8)$ & $50.0 b, c(2.9)$ & $1.0 \mathrm{a}(0.1)$ & $1.0 \mathrm{a}, \mathrm{b}(0.4)$ \\
\hline & 60 & 3.1d,e $(0.4)$ & $62.0 \mathrm{a}(1.5)$ & $53.0 \mathrm{c}(3.9)$ & $1.23 a, b(0.05)$ & $1.18 \mathrm{a}, \mathrm{b}(0.01)$ \\
\hline & 90 & $2.5 b, c . d(0.4)$ & 66.0a,b (1.4) & $52.0 \mathrm{c}(2.3)$ & $1.1 \mathrm{a}(0.3)$ & $1.2 \mathrm{a}, \mathrm{b}(0.3)$ \\
\hline
\end{tabular}

conditions (i.e., low pH, bile salts and lytic enzymes) on bacterial cultivability does represent an important issue as not doing so may lead to overestimations on the concentration of probiotics reaching the gut. It is worth mentioning that even in the worst scenario (apple snacks stored for 90 days followed by simulated gastric and intestinal digestion) the lactobacilli load was still high enough $\left(1.0 \times 10^{6} \pm 0.4 \times 10^{6} \mathrm{CFU} /\right.$ g) to assure that the ingestion of a normal size serving of about $25 \mathrm{~g}$ of snacks allows reaching the required concentration of microorganisms in the gut to exert a beneficial effect.

\subsection{Moisture content, texture, color and ascorbic acid retention of the snacks}

The properties of snacks coated with MC films containing microorganisms during storage are shown in Table 1 . The snacks baked at $140{ }^{\circ} \mathrm{C}$ for $30 \mathrm{~min}$ without any coating (controls) exhibited a moisture content close to $1.78 \%$ (ds). For the snack coated MC containing bacteria, the moisture content was about twice as much, and this value remained unchanged after 90 days of storage (Table 1). Although the values of hardness followed a similar trend, this fact was not reflected in the mechanical pattern. The obtained force-deformation curves of both the control and the coated snacks before storage (time: 0) showed a typical pattern of brittle materials, since they exhibited high values of force and low values of deformation at maximum breaking force (Fig. 3). The mechanical pattern of the bacterium-coated snacks was characterized by an average force of $1.55 \mathrm{~N}$ at the break value that did not change up to 90 days of storage. In addition, the deformation (depletion) did not show significant differences $(\mathrm{P}>0.05)$ at the breaking point. In all the cases, an abrupt slope and small drops in force due to small cracks characteristic of a brittle material could be observed (Fig. 3). Several authors reported that these drops indicate crispness related to a desirable texture for a snack (Hofsetz \& Lopes, 2005; Varela, Chen, Fiszman, \& Povey, 2006; Vincent, 1998).

After 120 days of storage, the bacterium-coated snacks showed a pattern with a smooth slope extended for longer time without the occurrence of sharp drops, a typical behavior of a ductile material due to the plasticizing effect of water content.
From Fig. 3, it can be inferred that a collapse of the structure occurred as a consequence of the water uptake during storage. Tavera-Quiroz et al. (2014) observed that isomalt has a protective effect on the apple tissue submitted to high temperatures, which was also shown by the BI calculated from Eq. 1 in the present work (Table 1), thus confirming that isomalt reduces the caramelization reaction (O'Brien-Nabors, 2001). A higher BI value was observed upon the addition of MC films containing microorganisms obtained at $60^{\circ} \mathrm{C}$ for $50 \mathrm{~min}$. The increase of BI, after the edible coating of the snack was applied, is a logical consequence of this additional heating process needed to dry the snack again. However, this BI increase would have been higher without the addition of isomalt, indicating that isomalt had a protective effect not only during the baking process but also during the drying period.

On the other hand, this protective effect of isomalt was also observed on the retention of AA. In the previous work, Tavera-Quiroz et al. (2015) found that the retention of AA in untreated apple rings submitted to baking at $140{ }^{\circ} \mathrm{C}$ for $30 \mathrm{~min}$

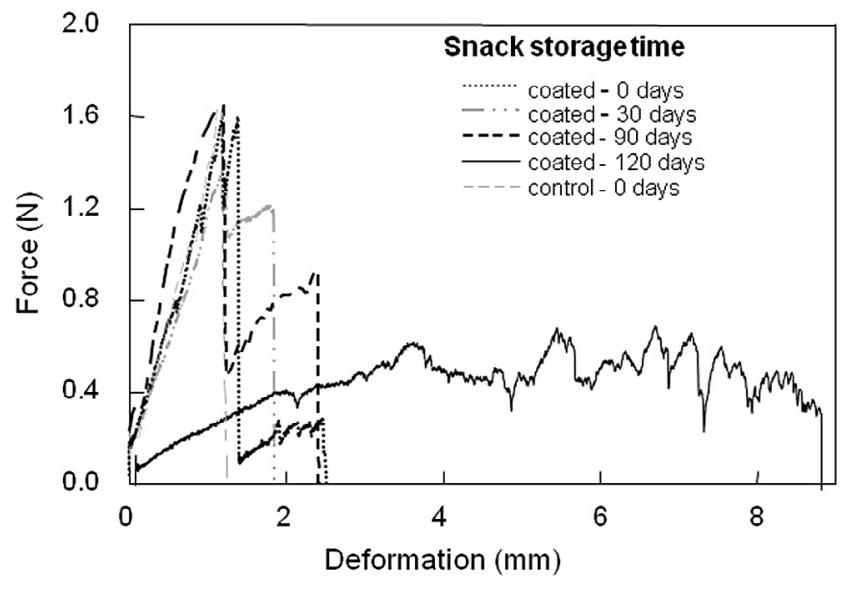

Fig. 3 - Mechanical behavior (force-deformation curves) for the snacks coated with MC films containing L. plantarum CIDCA 83114 and the uncoated snacks (control). The snacks were stored at $20^{\circ} \mathrm{C}$ and $60 \% \mathrm{RH}$ for $0,30,90$ and 120 days. 


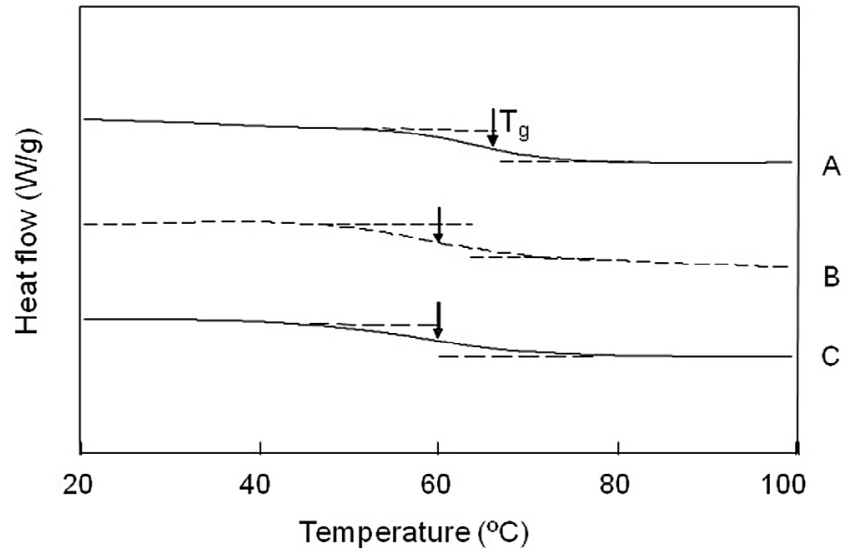

Fig. 4 - DSC thermograms of snacks coated with MC films functionalized with L. plantarum CIDCA 83114. Snacks were stored at $20{ }^{\circ} \mathrm{C}$ and $60 \% \mathrm{RH}$. Uncoated snacks (control, A), snacks coated with bacteria before (B) and after 90 days (C) of storage. Glass transition temperatures $\left(T_{g}\right)$ were obtained from the second scan. The arrows indicate the inflection point of the $\mathrm{T}_{\mathrm{g}}$.

was $15 \%$. The addition of about $50 \mathrm{mg} / \mathrm{g}_{\mathrm{ds}}$ AA simultaneously with isomalt during the impregnation of the apple slices (section 2.3 "Apple snack preparation") turned out to be $24.5 \mathrm{mg} / \mathrm{g}_{\mathrm{ds}}$ on average in both uncoated and coated snacks (retention about $50 \%)$. AA content in the uncoated control was determined immediately after baking at $140{ }^{\circ} \mathrm{C}$ for $30 \mathrm{~min}$, whereas in the coated sample AA was quantified after drying of the coating loaded with L. plantarum at $60^{\circ} \mathrm{C}$ for $50 \mathrm{~min}$. Therefore, this greater retention was supported by the addition of isomalt. It is expected that this amount of AA promoted beneficial effects on the consumer's health.

\subsection{Structural analysis and thermal properties of} the snacks

The control uncoated snacks had a $\mathrm{T}_{\mathrm{g}}$ of $68^{\circ} \mathrm{C}$ (Fig. 4 curve A) whereas the snacks coated with $\mathrm{MC}$ films containing microorganisms exhibited a value of $58{ }^{\circ} \mathrm{C}$ (Fig. 4 curve B). After 90 days of storage, the $\mathrm{T}_{\mathrm{g}}$ of coated snacks turned out to be about $57^{\circ} \mathrm{C}$ (Fig. 4 curve $\left.\mathrm{C}\right)$, showing no significant differences $(\mathrm{P}>0.05)$ with regard to that obtained at initial time. Although $\mathrm{T}_{\mathrm{g}}$ underwent a shift toward a lower value, $\mathrm{T}_{\mathrm{g}}$ of coated snack stayed almost constant at a temperature much higher than the room temperature, which was the selected temperature for snack storage $\left(\mathrm{T}=20^{\circ} \mathrm{C}\right)$. At this temperature the difference $\mathrm{T}-\mathrm{T}_{\mathrm{g}}$ is sufficient to guarantee the glassy state of the product. These results were consistent with the moisture content since the control presented a lower value (1.78\% db) (Table 1$)$.

As moisture content increased after 90 days of storage, the $\mathrm{T}_{\mathrm{g}}$ decreased and a smooth slope in force-deformation curve was obtained as above mentioned in section "Moisture content, texture, color and ascorbic acid retention of the snacks" (Fig. 3).

Fig. 5 shows the scanning microscopy images of the apple snack coated with MC films containing L. plantarum CIDCA 83114. A complete embedding of microorganisms in the film
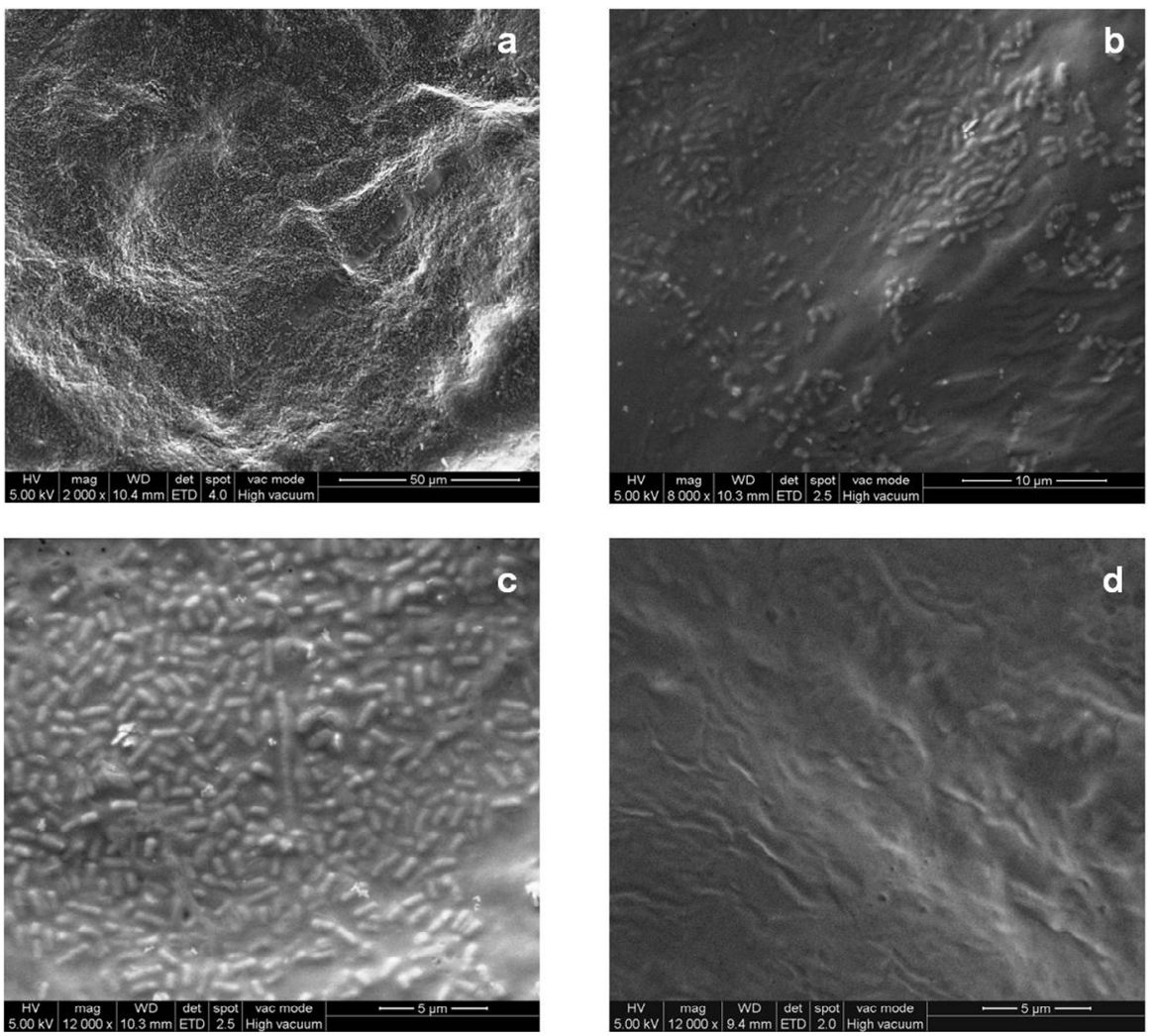

Fig. 5 - Scanning electron microscopy of snacks coated with a MC film functionalized with L. plantarum CIDCA 83114 at different resolutions ( $a, b$ and $c$ ) and control snack (d). Scale bars are indicated in the images. 
matrices, without alteration of bacterial morphology, was observed.

\subsection{Sensory panel}

In the present work, the effect of coating snacks with probiotics was evaluated. Fig. 6 shows the frequency, which corresponds to the number of panelists that chose a category over the total number of panelists (50), as a function of the categories of sensory properties. Panelists did not reject any sample; in all cases, scores were higher than five (considered in the present work as the minimum acceptable value) and in the majority of the cases, they were close to seven or eight (Fig. 6a). The taste score of the snack coated with the microorganisms immobilized in MC film was significantly lower $(P<0.05)$ to the control values (6.5 \pm 0.6 and $7.2 \pm 0.4$, respectively) (Fig. 6b). Considering the color attribute, panelists gave a higher score to the coated snack $(7.7 \pm 0.4)$ compared to the control $(7.4 \pm 0.4)$, because the more prolonged time of drying $\left(140{ }^{\circ} \mathrm{C} / 30 \mathrm{~min}\right.$ and
$60{ }^{\circ} \mathrm{C} / 50 \mathrm{~min}$, see section "Drying process") allowed a greater development of the caramelization reaction, leading to higher BI values (Fig. $6 \mathrm{c}$ and Table 1). In regard to the texture attribute (Fig. 6d), panelists gave a slightly lower score to snacks coated with probiotics $(7.9 \pm 0.5$ and $7.2 \pm 0.4$, for control and coated snack, respectively), perhaps owing to the higher value of moisture of the samples, as can be seen in Table 1. However, as shown in Fig. 3 (see section "Moisture content, texture, color and ascorbic acid retention of the snacks"), the values of hardness followed a similar trend in both snacks with no influence in the mechanical pattern even after 90 days of storage (Fig. 3a). Finally, the overall acceptability scores obtained for the control and coated snacks $(7.7 \pm 0.3$ and $7.2 \pm 0.4$, respectively) did not present significant differences $(P>0.05)$ (Fig. 6e). The results presented in Fig. 6a-e demonstrate as a whole that coating the apple snacks with probiotics immobilized in MC films does not alter their very good sensory attributes. This is of great significance, taking into account the added value of the coated snacks. a
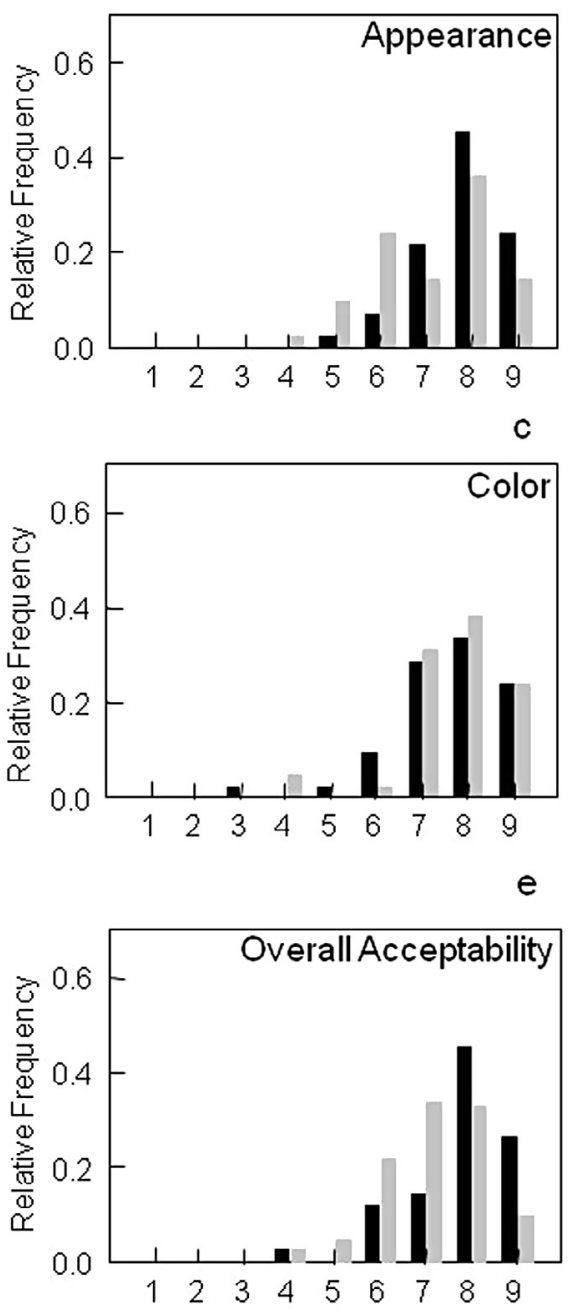

b
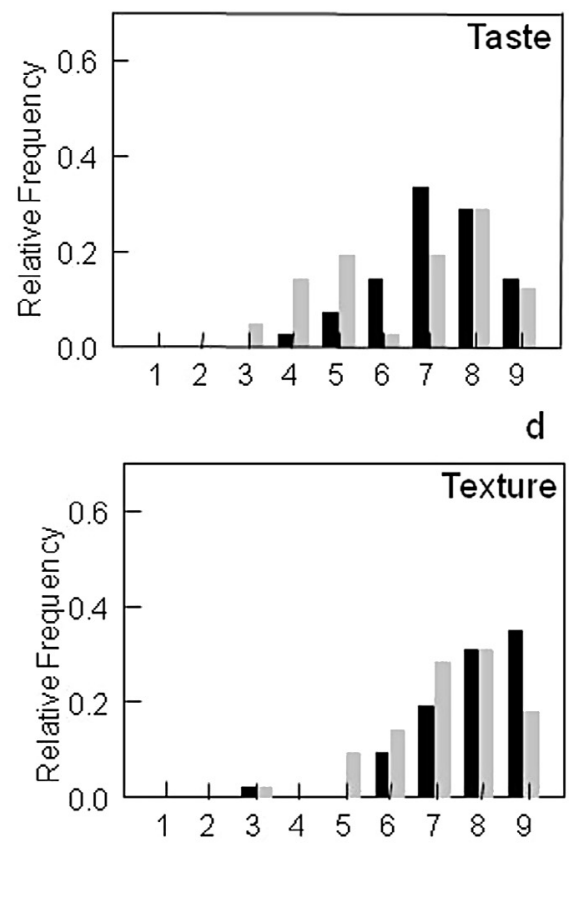

Fig. 6 - Sensory evaluation of the apple snacks for the following attributes: (a) appearance; (b) taste; (c) color; (d) texture; (e) overall acceptability. Frequency: number of panelists that choose a category/total number of panelists (50). Category: from 1 (dislike extremely) to 9 (like extremely). Snacks coated with MC containing L. plantarum CIDCA 83114: gray bars. Controls (uncoated snack): black bars. 


\section{Conclusions}

Taking advantage of their increasing consumption by the population, snacks appear to be adequate carriers for the incorporation of functional compounds. In the present work, we coated apple snacks, formulated with isomalt, calcium and AA, with a film containing probiotic microorganisms. The incorporation of microorganisms to obtain functional foods is a challenge because of several factors potentially detrimental for microorganisms. Among them, food processing, storage and passage through the gastro-intestinal tract are the most important ones. The conditions defined in this work allowed overcoming all these harmful effects, obtaining snacks containing a high concentration of cultivable microorganisms. Indeed, it must be emphasized that the cultivability of L. plantarum CIDCA 83114 was around $10^{6} \mathrm{CFU} / \mathrm{g}$ after both 90 days of storage and the contact with a simulated gastrointestinal environment. These values assure that the ingestion of a normal snack size serving of about $25 \mathrm{~g}$ leads to a bacterial concentration above that required by the international organizations (EFSA and FDA) for a product to be considered as probiotic at the moment of consumption.

\section{Acknowledgments}

This work was supported by the Argentinean Agency for the Scientific and Technological Promotion (ANPCyT) (Projects PICT/ 2011/0226 440 and PICT/2012/0415) and the Argentinean National Research Council (CONICET) (PIP2012-2014114-20110100024). Authors acknowledge Claudio Reyes and Daniel Russo for technical assistance. P.M., N.B., A.P. and A.G.-Z. are members of the research career CONICET. M.J.T.-Q. and N.R. are doctoral fellows from CONICET and ANPCyT, respectively.

\section{R E F E R E N C E S}

Altamirano-Fortoul, R., Moreno-Terrazas, R., Quezada-Gallo, A., \& Rosell, C. M. (2012). Viability of some probiotic coatings in bread and its effect on the crust mechanical properties. Food Hydrocolloids, 29, 166-174.

Association of Official Analytical Chemists. (1980). AOAC Official methods of analysis (13th ed.). Washington, DC.

Bedani, R., Vieira, A. D. S., Rossi, E. A., \& Saad, S. M. I. (2014). Tropical fruit pulps decreased probiotic survival to in vitro gastrointestinal stress in synbiotic soy yoghurt with okara during storage. LWT - Food Science and Technology, 55, 436-443.

Buriti, F. C. A., Castro, I. A., \& Saad, S. M. I. (2010). Viability of Lactobacillus acidophilus in synbiotic guava mousses and its survival under in vitro simulated gastrointestinal conditions. International Journal of Food Microbiology, 137, 121-129.

Bustos, P., \& Bórquez, R. (2013). Influence of osmotic stress and encapsulating materials on the stability of autochthonous Lactobacillus plantarum after spray drying. Drying Technology, 31, 57-66.

Cammenga, H. K., \& Zielasko, B. (1996). Thermal behaviour of isomalt. Thermochimica Acta, 271, 149-153.

Champagne, C. P., Gardner, N. J., \& Roy, D. (2005). Challenges in the addition of probiotic cultures to foods. Critical Reviews in Food Science and Nutrition, 45, 61-84.
Chong, E. (2014). A potential role of probiotics in colorectal cancer prevention: Review of possible mechanisms of action. World Journal of Microbiology and Biotechnology, 30, 351-374.

de Man, J. C., Rogosa, M., \& Sharpe, M. E. (1960). A medium for the cultivation of lactobacilli. Journal of Applied Bacteriology, 23, 130-135.

FAO/WHO. (2002). Evaluation of health and nutritional properties of probiotics in food including powder milk with live lactic acid bacteria. <ftp://ftp.fao.org/es/esn/food/wgreport2.pdf> Accessed 08.09.14.

Garrote, G. L., Abraham, A. G., \& De Antoni, G. L. (2001). Chemical and microbiological characterisation of kefir grains. Journal of Dairy Research, 68, 639-652.

Golowczyc, M., Gerez, C., Silva, J., Abraham, A., De Antoni, G. L., \& Teixeira, P. (2011). Survival of spray-dried Lactobacillus kefir is affected by different protectants and storage conditions. Biotechnology Letters, 33, 681-686.

Golowczyc, M., Silva, J., Teixeira, P., De Antoni, G. L., \& Abraham, A. (2011). Cellular injuries of spray-dried Lactobacillus spp. isolated from kefir and their impact on probiotic properties. International Journal of Food Microbiology, 144, 556-560.

Gostner, A., Blaut, M., Schäffer, V., Kozianowski, G., Theis, S., Klingeberg, M., Dombrowski, Y., Martin, D., Ehrhardt, S., Taras, D., Schwiertz, A., Kleessen, B., Lührs, H., Schauber, J., Dorbath, D., Menzel, T., \& Scheppach, W. (2006). Effect of isomalt consumption on faecal microflora and colonic metabolism in healthy volunteers. British Journal of Nutrition, 95, 40-50.

Hill, C., Guarner, F., Reid, G., Gibson, G. R., Merenstein, D. J., Pot, B., Morelli, L., Berni Canani, R., Flint, H. J., Salminen, S., Calder, P. C., \& Sanders, M. E. (2014). Expert consensus document: The International Scientific Association for Probiotics and Prebiotics consensus statement on the scope and appropriate use of the term probiotic. Nature Reviews Gastroenterology \& Hepatology, 11, 506-514.

Hofsetz, K., \& Lopes, C. C. (2005). Crispy banana obtained by the combination of a high temperature and short time drying stage and a drying process. Brazilian Journal of Chemical Engineering, 22, 285-292.

Hugo, A. A., Kakisu, E., De Antoni, G. L., \& Pérez, P. F. (2008). Lactobacilli antagonize biological effects of enterohaemorrhagic Escherichia coli in vitro. Letters in Applied Microbiology, 46, 613-619.

Kakisu, E., Abraham, A. G., Tironi Farinati, C., Ibarra, C., \& De Antoni, G. L. (2013a). Lactobacillus plantarum isolated from kefir protects vero cells from cytotoxicity by type-II Shiga toxin from Escherichia coli 0157:H7. Journal of Dairy Research, 80, 6471.

Kakisu, E., Bolla, P., Abraham, A. G., de Urraza, P., \& De Antoni, G. L. (2013b). Lactobacillus plantarum isolated from kefir: Protection of cultured Hep-2 cells against Shigella invasion. International Dairy Journal, 33, 22-26.

Kanmani, P., \& Lim, S. T. (2013). Development and characterization of novel probiotic-residing pullulan/starch edible films. Food Chemistry, 141, 1041-1049.

Komatsu, T. R., Buriti, F. C. A., \& Saad, S. M. I. (2008). Overcoming hurdles through innovation, persistence and creativeness in the development of probiotic foods. Brazilian Journal of Pharmaceutical Sciences, 44, 329-347.

Kumar, M., Kumar, A., Nagpal, R., Mohania, D., Behare, P., Verma, V., Kumar, P., Poddar, D., Aggarwal, P. K., Henry, C. J., Jain, S., \& Yadav, H. (2010). Cancer-preventing attributes of probiotics: An update. International Journal of Food Sciences and Nutrition, 61, 473-496.

Lapsiri, W., Bhandari, B., \& Wanchaitanawong, P. (2012). Viability of Lactobacillus plantarum TISTR 2075 in different protectants during spray drying and storage. Drying Technology. An International Journal, 30, 1407-1412. 
López de Lacey, A. M., López-Caballero, M. E., Gómez-Estaca, J., Gómez-Guillén, M. C., \& Montero, P. (2012). Functionality of Lactobacillus acidophilus and Bifidobacterium bifidum incorporated to edible coatings and films. Innovative Food Science \& Emerging Technologies, 16, 277-282.

López de Lacey, A. M., López-Caballero, M. E., \& Montero, P. (2014). Agar films containing green tea extract and probiotic bacteria for extending fish shelf-life. LWT - Food Science and Technology, 55, 559-564.

Martínez-Cervera, S., Salvador, A., \& Sanz, T. (2014). Comparison of different polyols as total sucrose replacers in muffins: Thermal, rheological, texture and acceptability properties. Food Hydrocolloids, 35, 1-8.

Nojavan, S., Khaliliana, F., Momen Kiaiec, F., Rahimic, A., Arabanianc, A., \& Chalavia, S. (2008). Extraction and quantitative determination of ascorbic acid during different maturity stages of Rosa canina L. fruit. Journal of Food Composition and Analysis, 21, 300-305.

Noorbakhsh, R., Yaghmaee, P., \& Durance, T. (2013). Radiant energy under vacuum (REV) technology: A novel approach for producing probiotic enriched apple snacks. Journal of Functional Foods, 5, 1049-1056.

O'Brien-Nabors, L. (2001). Isomalt. In M. C. Wijers \& P. J. Strater (Eds.), Alternative sweeteners (Third ed., pp. 265-282). New York: Lyn Marcel Dekker, Inc.

Radowski, A. (2006). Isomalt in breakfast cereals, granola bars, and muesli. Cereals Food World, 51, 254-256.

Rajam, R., Karthik, P., Parthasarathi, S., Joseph, G. S., \& Anandharamakrishnan, C. (2012). Effect of whey protein alginate wall systems on survival of microencapsulated Lactobacillus plantarum in simulated gastrointestinal conditions. Journal of Functional Foods, 4(4), 891-898.

Raudonus, J., Bernard, J., Janßen, H., Kowalczyk, J., \& Carle, R. (2000). Effect of oligomeric or polymeric additives on glass transition, viscosity and crystallization of amorphous isomalt. Food Research International, 33, 41-51.

Romano, N., Tavera-Quiroz, M. J., Bertola, N., Mobili, P., Pinotti, A., \& Gómez-Zavaglia, A. (2014). Edible methylcellulose-based films containing fructo-oligosaccharides as vehicles for lactic acid bacteria. Food Research International, 64, 560-566.

Rößle, C., Brunton, N., Gormley, R. T., Ross, P. R., \& Butler, F. (2010). Development of potentially synbiotic fresh-cut apple slices. Journal of Functional Foods, 2, 245-254.

Saad, N., Delattre, C., Urdaci, M., Schmitter, J. M., \& Bressollier, P. (2013). An overview of the last advances in probiotic and prebiotic field. LWT - Food Science and Technology, 50, 1-16.

Saad, S. M. I. (2006). Probiotics and prebiotics: The state of the art. Brazilian Journal of Pharmaceutical Sciences, 42, 1-16.

Senaka Ranadheera, C., Evans, C. A., Adams, M. C., \& Baines, S. K. (2014). Effect of dairy probiotic combinations on in vitro gastrointestinal tolerance, intestinal epithelial cell adhesion and cytokine secretion. Journal of Functional Foods, 8 , 18-25.

Soukoulis, C., Behboudi-Jobbehdar, S., Yonekura, L., Parmenter, C., \& Fisk, I. (2014). Stability of Lactobacillus rhamnosus GG in prebiotic edible films. Food Chemistry, 159, 302-308.

Soukoulis, C., Yonekura, L., Gan, H.-H., Behboudi-Jobbehdar, S., Parmenter, C., \& Fisk, I. (2014). Probiotic edible films as a new strategy for developing functional bakery products: The case of pan bread. Food Hydrocolloids, 39, 231-242.

Tapia, M. S., Rojas-Graü, M. A., Rodríguez, F. J., Ramírez, J., Carmona, A., \& MartinBelloso, O. (2007). Alginate and gellanbased edible films for probiotic coatings on fresh-cut fruits. Journal of Food Science, 72, 190-196.

Tavera-Quiroz, M. J., Urriza, M., Pinotti, A., \& Bertola, N. (2014). Development and characterization of a baked snack from rings of green apples. Food and Bioprocess Technology, 7, 22182227.

Tavera-Quiroz, M. J., Urriza, M., Pinotti, A., \& Bertola, N. (2015). Baked snack from green apples formulated with the addition of isomalt. LWT - Food Science and Technology, 62, 1004-1010.

Tripathi, M. K., \& Giri, S. K. (2014). Probiotic functional foods: Survival of probiotics during processing and storage. Journal of Functional Foods, 9, 225-241.

Tymczyszyn, E. E., Díaz, M. R., Gómez-Zavaglia, A., \& Disalvo, E. A. (2007a). Volume recovery, surface properties and membrane integrity of Lactobacillus delbrueckii subsp.bulgaricus dehydrated in the presence of trehalose or sucrose. Journal of Applied Microbiology, 103, 2410-2419.

Tymczyszyn, E. E., Gómez-Zavaglia, A., \& Disalvo, E. A. (2007b). Effect of sugars and growth media on the dehydration of Lactobacillus delbrueckii ssp. bulgaricus. Journal of Applied Microbiology, 102, 845-851.

Varela, P., Chen, J., Fiszman, S., \& Povey, M. J. W. (2006). Crispness assessment of roasted almonds by an integrated approach to texture description: Texture, acoustics, sensory and structure. Journal of Chemometrics, 20, 311-320.

Vincent, J. F. (1998). The quantification of crispness. Journal of the Science of Food and Agriculture, 78, 162-168. 